\title{
FENITROTHIONAND ESFENVALERATE STABILITY DURING CORN AND WHEAT SAMPLE PROCESSING
}

\author{
Javier Alberto Vásquez-Castro ${ }^{1 *}$; Gilberto Casadei de Baptista ${ }^{2}$; Luiz Roberto Pimentel \\ Trevizan $^{3}$; Casimiro Dias Gadanha Junior ${ }^{4}$ \\ ${ }^{1}$ Universidad Nacional Agraria La Molina - Depto. de Entomología, Av. La Universidad s/n, apartado postal \\ 456, Lima - Perú. \\ ${ }^{2}$ USP/ESALQ - Depto. de Entomologia, Fitopatologia e Zoologia Agrícola - C.P. 09 - 13418-900 - Piracicaba, SP - \\ Brasil. \\ ${ }^{3}$ USP/ESALQ - Programa de Pós-Graduação em Entomologia. \\ ${ }^{4} U S P / E S A L Q$ - Depto. de Engenharia Rural. \\ *Corresponding author<jaque@lamolina.edu.pe>
}

\begin{abstract}
The presence of insecticide residues in cereals represents a risk for the consumer, because these substances are used in large scale to protect stored grains from the attack of pests. The effects of three processing methods for corn and wheat samples on the stability of stored-grain protective insecticides were here evaluated. Fenitrothion and esfenvalerate were applied so as to produce theoretical concentrations of 10 and $0.5 \mathrm{mg} \mathrm{kg}^{-1}$, respectively. Two hours after treatment, the grains were processed and deposition was analyzed by gas chromatography. Grain species did not influence insecticide stability. This stability was only dependent upon the processing method and insecticide type. Grains processed together with dry ice provided the greatest percentage of recovery for both insecticides. Regardless of the processing method, more esfenvalerate than fenitrothion was recovered, thus demonstrating the greater stability of the pyrethroid during this operation.

Key words: stored grain, insecticide degradation, dry ice, gas chromatography
\end{abstract}

\section{ESTABILIDADE DE FENITROTION E ESFENVALERATO DURANTE O PROCESSAMENTO DE AMOSTRAS DE MILHO E TRIGO}

\begin{abstract}
RESUMO: A presença de resíduos de inseticida em amostras de cereais representa um risco ao consumidor, pois estas substâncias são empregadas em larga escala na preservação de grãos armazenados. Neste sentido, o efeito de três métodos de processamento de amostras de milho e trigo na estabilidade de inseticidas protetores de grãos armazenados foram avaliados. $\mathrm{O}$ fenitrotion e o esfenvalerato foram aplicados de modo a produzir concentração teórica de 10 e $0,5 \mathrm{mg} \mathrm{kg}^{-1}$, respectivamente. Duas horas após o tratamento, os grãos foram processados e os depósitos analisados mediante cromatografia gasosa. A espécie de grão não teve influência na estabilidade dos inseticidas, sendo que essa estabilidade apenas dependeu do método de processamento e do inseticida. Os grãos processados junto com gelo seco proporcionaram a maior porcentagem de recuperação de ambos os inseticidas. Independente do método de processamento utilizado, conseguiu-se recuperar mais esfenvalerado do que fenitrotion, demonstrando-se assim, a maior estabilidade do piretróide durante esta operação.

Palavras-chave: grãos armazenados, degradação de inseticida, gelo seco, cromatografia gasosa
\end{abstract}

\section{INTRODUCTION}

To prevent human populations from consuming foods with dangerous levels of insecticides, every registered product is accompanied by a maximum residue limit (MRL) allowed by law for each agricultural product. The risk becomes more apparent when laboratories specialized in residue analysis show inconsistent results, as a consequence of a high degree of uncertainty in the reliability of the analytical procedures.
In pesticide residue studies on plant materials, the phase that precedes the analytical step can be divided into sample processing and subsampling (Silva et al., 2003). Sample processing is one of the steps that can influence the uncertainty and precision of the results, because during this stage the pesticides may become volatilized and subject to hydrolysis and enzymatic reactions (Ambrus, 2004). This loss may lead to underestimation errors of the amounts of residues present in food, and may put consumer's health at risk. 
The organophosphorus insecticide fenitrothion and the pyrethroid esfenvalerate are among the insecticides registered in Brazil for stored grain treatment (Anvisa, 2005). Both have different physicochemical properties which may influence their stability during sample processing in machines that generate heat. The objective of this study was to evaluate the effects of three processing methods for corn and wheat grains on the stability of fenitrothion and esfenvalerate.

\section{MATERIAL AND METHODS}

The experiment was carried out in Piracicaba, State of São Paulo, Brazil, using corn and wheat cultivars Sol-da-Manhã and BRS 208. Fenitrothion and esfenvalerate (structural formulae Figures 1 and 2) were applied so as to produce theoretical concentrations of 10 and $0.5 \mathrm{mg} \mathrm{kg}^{-1}$, respectively. A commercial product, containg $500 \mathrm{~g}$ of the a.i. fenitrothion $+25 \mathrm{~g}$ of the a.i. esfenvalerate per liter, was used. For treatment purposes, corn and wheat were packaged into plastic bags. The application was performed with a sprayer attached to an air compressor with a constant pressure of $150 \mathrm{kPa}$, using $22.5 \mathrm{~mL}$ of insecticide emulsion (1:250 dilution of the commercial product in water) for $4.5 \mathrm{~kg}$ of grain $\left(5 \mathrm{~L} \mathrm{t}^{-1}\right)$. During the spraying operation, the bags were agitated manually, allowing the mix to be distributed as homogeneously as possible. The same procedure was adopted for the control treatment, but in this case the spray consisted of water only. The temperature and relative humidity during spray were $26.2^{\circ} \mathrm{C}$ and $87 \%$, respectively.

Two hours after spraying, $0.5 \mathrm{~kg}$ of corn and wheat grains were collected and processed by one of the three processing methods: grains ground without dry

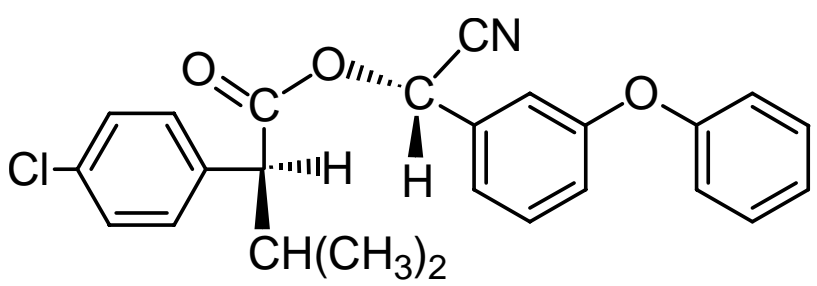

Figure 1 - Esfenvalerate structural formula: $(S)$ - $\alpha$-cyano -3-phenoxybenzyl $(S)$-2-(4-chlorophenyl)-3Methylbutyrate.

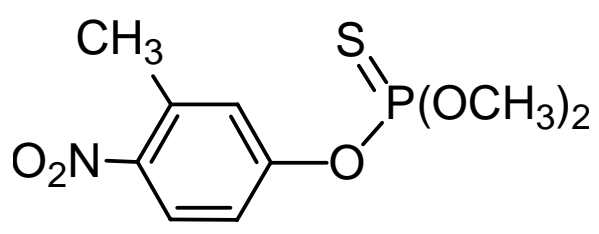

Figure 2 - Fenitrothion structural formula: $O, O$-dimethyl $O$-4nitro- $m$-tolyl phosphorothioate. ice, grains ground with dry ice, and grains without processing. Three replicates were made, generating 18 experimental plots, and two insecticides were analyzed, totaling 36 subplots. In the first two methods, the grains were ground in a model TRF70 forage chopper; in the second method, the dry ice was mixed with the grains at a 1:1 ratio prior to grinding. In the third method, the whole grains were taken directly to the laboratory for the respective analysis. The temperature and relative humidity during processing were $29.1{ }^{\circ} \mathrm{C}$ and $86 \%$, respectively. The analytical method was adapted from Ohlin (1998), by which ten grams of homogenized samples were placed in $100 \mathrm{~mL}$ Schott bottles for residue extraction. Fifty $\mathrm{mL}$ ethyl acetate and $10 \mathrm{~g}$ sodium sulfate were added and later homogenized in a stirring table for 1 hour at 360 cycles $\min ^{-1}$. After this operation, the extracts were centrifuged for 5 minutes at 1,325 $\mathrm{g}$ for better separation of the liquid phase from suspension materials. Ten milliliter aliquots of the supernatant were transferred to $12-\mathrm{mL}$ test tubes, corresponding to $2 \mathrm{~g}$ of the original sample, and were then added of $50 \mu \mathrm{L}$ dodecane. The extracts were evaporated in a Turbo-Vap evaporator in a water bath at $30^{\circ} \mathrm{C}$ aided by moving air previously dried through a blue silica gel desiccant filter. The insecticide residues were then resuspended in $5 \mathrm{~mL}$ of a cyclohexane / ethyl acetate mixture $(1: 1, \mathrm{v} / \mathrm{v})$, homogenized in vortex mixer/ultrasound and filtered through a Millipore, FG, $0.2 \mu \mathrm{m}$ pore membrane filter mounted on a plastic hypodermic syringe $(5 \mathrm{~mL})$. The extracts were cleaned by gel permeation chromatography (GPC) and eluted with a cyclohexane / ethyl acetate mixture $(1: 1, \mathrm{v} / \mathrm{v})$. After this operation, the extracts were evaporated in a Turbo-Vap evaporator previously added of $50 \mu \mathrm{L}$ dodecane and were later resuspended in 20.0 and $1.95 \mathrm{~mL}$ of the cyclohexane / ethyl acetate mixture $(1: 1, \mathrm{v} / \mathrm{v})$ for the fenitrothion and esfenvalerate residues, respectively.

Samples were analyzed by gas chromatography, using a Thermo Quest gas chromatograph, model Trace, equipped with an electron capture detector (ECD, $\mathrm{Ni}^{63}$ ) and capillary chromatographic column Restek Corp. RTX-5MS, 30m-length, 0.25-mm internal diameter, and $0.25-\mathrm{mm}$ film thickness, with injections made in the splitless mode. The chromatograph was operated under the following conditions: column temperature $=$ $100^{\circ} \mathrm{C}$ (initial); then at $280^{\circ} \mathrm{C}\left(25^{\circ} \mathrm{C} \mathrm{min}^{-1} \mathrm{ramp}\right)$, remaining at this temperature for a period of ten minutes; injector temperature $=230^{\circ} \mathrm{C}$; detector temperature $=$ $320^{\circ} \mathrm{C}$, purge time $=0.75$ minute; gas flow $\left(\mathrm{mL} \mathrm{min}^{-1}\right)$ : $\mathrm{H}_{2}$ (carrier) $=1.2 ; \mathrm{N}_{2}$ (make up) $=45$ and purge flow $=65$; run time $=18$ minutes and 15 seconds. Under these conditions, retention time was 7 minutes and 5 seconds for fenitrothion and 12 minutes and $40 \mathrm{sec}-$ onds for esfenvalerate, approximately. 
The residues were calculated using the ChromQuest version 4.1 software, based on a previously plotted calibration curve $\left(r^{2}=0.9995\right.$ and 0.9999 for fenitrothion and esfenvalerate, respectively), obtained from injections of 5, 10, 20, 40, 100, and 200 pg of fenitrothion and esfenvalerate analytical standard into the chromatographic system. The analytical method used for corn and wheat grains was validated by means of matrix fortification at the levels of 0.05 , 0.5 , and $10.0 \mathrm{mg} \mathrm{kg}^{-1}$ for fenitrothion and $0.05,0.1$, and $1.0 \mathrm{mg} \mathrm{kg}^{-1}$ for esfenvalerate, with three replicates for each level (nine fortified samples for each matrix). Recoveries between 70 - 120\% were considered acceptable.

Data were submitted to analysis of variance, using a mathematical model for a completely randomized design in a split-plot arrangement, and the $\mathrm{F}$ test was used to evaluate the significance of factors (grain species, processing method, insecticide and interactions) in the model (Steel \& Torrie, 1960; Gomes, 1987). Because the processing method factor was a qualitative variable with three levels, whenever the $\mathrm{F}$ test detected a significant difference between its means or between the means of the interaction, a detailed analysis was obtained by the Tukey test, considering a minimum significance level of 5\% $(P<0.05)$. Since the grain species and insecticide factors have only two levels, the $\mathrm{F}$ test in the analysis of variance is already conclusive.

\section{RESULTS AND DISCUSSION}

The insecticide recovery percentages in the fortified corn and wheat grains were acceptable (70 $120 \%$ ), thus validating the analytical method. None of the two insecticides was recovered from the control, indicating that the grains were free from contamination by those compounds. The analysis of variance only detected effects $(P<0.05)$ for processing method and insecticide. Neither grain species nor any of the interactions influenced insecticide stability, which was dependent only upon insecticide and processing method when used individually. The processing method where the grains were ground mixed with dry ice pro- vided the highest recovery percentage in both insecticides, and was significantly different from the other two methods by (Table 1). Regardless of processing method used, more esfenvalerate than fenitrothion was recovered, thus demonstrating the greater stability of the pyrethroid when compared with the organophosphorus insecticide.

Esfenvalerate recovery was higher than $100 \%$ in non-processed grains and in those processed with dry ice. Later, a flow increase was verified in the spraying system, even when working at constant pressure, therefore producing higher deposits than those intended. The problem verified during spray does not compromise the results of this experiment, because only one spray was performed for each grain species, and then the samples were collected and processed by one of the three methods. In view of this, all treatments (processing methods) received the same amount of insecticide. The later recovery of insecticides was dependent exclusively on the processing method and on the physicochemical characteristics of the molecule.

The mean temperatures in the samples before and after grinding without dry ice were 25 and $35^{\circ} \mathrm{C}$, respectively. The temperature increase during sample processing was one of the factors responsible for degradation of both insecticides. The temperature in the grain affected the velocity of reactions catalyzed by enzymes, and a $10^{\circ} \mathrm{C}$ increase could double the rate of these reactions (Rowlands, 1967). Losses between 40 and $70 \%$ in the theoretical rates of captan, captafol, folpet, chlorotalonil, and dichlofluanid were found in fruits and vegetables processed at room temperature (El-Bidaoui et al., 2000; Hill et al., 2000). The results described here coincide with those obtained by Fussell et al. (2002), which demonstrated the stability of 94 pesticides during processing of apple fruit frozen in the presence of dry ice (cryogenesis). On the other hand, studies on insecticide effectiveness and residues in stored grains can be found in the international bibliographic references showing small deposits right after spray, but with high effectiveness in the control of pests. This would be due in part to a loss of insecticides during sample processing at room temperature with a consequent underestimation of the deposit.

Table 1 - Means and standard errors for insecticide recovery percentage in corn and wheat grains as a function of processing method and insecticide.

\begin{tabular}{lrcr}
\hline \multirow{2}{*}{ Insecticide } & \multicolumn{3}{c}{ Processing Method } \\
\cline { 2 - 4 } & No Processing & Without Dry Ice & With Dry Ice \\
\hline Esfenvalerate & $105.7 \pm 4.2 \mathrm{bA}$ & $97.7 \pm 4.2 \mathrm{bA}$ & $122.3 \pm 4.2 \mathrm{aA}$ \\
Fenitrothion & $82.2 \pm 4.2 \mathrm{bB}$ & $77.6 \pm 4.2 \mathrm{bB}$ & $99.0 \pm 4.2 \mathrm{aB}$ \\
\hline
\end{tabular}

Means followed by different lower case letters in the rows differ by Tukey test $(P<0.05)$; means followed by different upper case letters in the columns differ by $\mathrm{F}$ test $(P<0.05)$. 
Non-processed grains had similar results to those obtained by grinding without dry ice, for both insecticides. The explanation for this result is that the insecticides penetrated whole grains, and were partially extracted during the extraction procedure. The insecticides we studied are contact insecticides; even so, they can penetrate and even move within the plant tissues (Finlayson \& MacCarthy, 1965). The rate at which contact insecticides penetrate stored grains affects their metabolic fate and the persistence of their residues, with degradation being directly proportional to penetration velocity (Rowlands, 1971). In addition to the physicochemical characteristics of the insecticide, formulation has great influence on penetration; lipophilic insecticides can penetrate more easily when formulated as emulsifiable concentrates (Ebeling, 1963), as were the insecticides in our study.

The following could be mentioned among the most important physicochemical characteristics for the stability of these insecticides: vapor pressure, with values of $2.010^{-7}$ and $1.810^{-2} \mathrm{~Pa}$; n-octanol-water partition coefficient $\left(\mathrm{K}_{\mathrm{ow}}\right)$, with logarithmic values of 6.22 and 3.43; solubility in water, with values of 0.002 and $21 \mathrm{mg} \mathrm{L}^{-1}$, and molecular weight, with values of 419.9 and 277.2 for esfenvalerate and fenitrothion, respectively (Tomlin, 1995). A greater vapor pressure means that the substance is more volatile; this explains the higher fenitrothion losses during spray and sample processing. Processing machines that produce temperature increases during this operation cause greater losses, especially of more volatile pesticides.

At smaller $\log \mathrm{K}_{\mathrm{ow}}$ values, the substance is more hydrophilic, and the more water-soluble the insecticide, the more easily it will penetrate the grain, thus increasing its degradation rate. Therefore, the smaller fenitrothion recovery in the non-processed grains was due to the incapability of the solvent to extract the insecticide, in addition to its higher degradation. Rowlands (1966 apud Rowlands, 1967) observed that $50 \%$ of a fenitrothion dose penetrated the wheat grain endosperm one hour after treatment; after two hours, half of the insecticide inside the grain had been degraded by acid phosphatases. Molecular size should also be taken into consideration in the estimation of insecticide solubility in water; as a rule, large molecules are less soluble than small molecules (Seiber, 1999); as a result, fenitrothion is more soluble than esfenvalerate. On the other hand, high temperatures increase the rate of degradation because substances become more soluble (Stenersen, 2004).

High uncertainty in analytical procedures, especially in the field of pesticide residues, where the detection of very small amounts of pesticides is sought, may lead to results that are at times unreliable and doubtful. The use of dry ice in sample processing procedures for pesticide residue analyses is highly recommended if greater confidence and precision of analytical results is desired.

\section{ACKNOWLEDGMENTS}

To the Programa de Estudante-Convênio de Pós-Graduação (PEC-PG) and to CNPq for the doctoral scholarship awarded to the first author.

\section{REFERENCES}

AGÊNCIA NACIONAL DE VIGILÂNCIA SANITÁRIA - ANVISA. Available at: http://www.anvisa.gov.br. Accessed 5 May 2006.

AMBRUS, A. Reliability of measurements of pesticide residues in food. Accreditation and Quality Assurance, v.9, p.288304, 2004.

EBELING, W. Analysis of the basic processes involved in the deposition, degradation, persistence, and effectiveness of pesticides. Residue Reviews, v.3, p.35-163, 1963.

EL-BIDAOUI, M.; JARJU, O.P.; MAESTRONI, M.; PHAKAEIW, Y.; AMBRUS, A. Testing the effect of sample processing and storage on stability of residues. In: FAJGELJ, A.; AMBRUS, A. (Ed.) Principles of method validation. Cambridge: Royal Society of Chemistry, 2000. p.75-88.

FINLAYSON, D.G.; MacCARTHY, H.R. The movement and persistence of insecticides in plant tissue. Residue Reviews, v.9, p.114-152, 1965.

FUSSELL, R.J.; ADDIE, K.J.; REYNOLDS, S.L.; WILSON, M.F. Assessment of stability of pesticides during cryogenic sample processing. 1. Apples. Journal of Agricultural and Food Chemistry, v.50, p.441-448, 2002.

GOMES, F.P. Curso de estatística experimental. São Paulo: Nobel, 1987. 466p.

HILL A.R.C.; HARRIS C.A.; WARBURTON, A.G. Effects of sample processing on pesticide residues in fruit and vegetables. In: FAJGelJ, A.; AMBrus, A. (Ed.) Principles of method validation. Cambridge: Royal Society of Chemistry, 2000. p.4148.

OHLIN, B. A capillary gas chromatography multi-residue method for the determination of pesticides in cereals and cereal products. In: National Food Administration. Pesticide analytical methods in Sweden. Uppsala: NFA, 1998. pt. 1, p.75-86.

ROWLANDS, D.G. The metabolism of contact insecticides in stored grains. Residue Reviews, v.17, p.105-177, 1967.

ROWLANDS, D.G. The metabolism of contact insecticides in stored grains. II. 1966-1969. Residue Reviews, v.34, p.91-161, 1971.

SEIBER, J.N. Extraction, cleanup, and fractionation methods. In: Winefordner, J.D. (Ed.) Pesticide residues in foods: methods, techniques, and regulations. New York: John Wiley, 1999. p.1761.

SILVA, R.J.N.B.; FIGUEIREDO, H.; SANTOS, J.R.; CAMÕES, M.F.G.F.C. Evaluation of sample processing and sub-sampling performance. Analytica Chimica Acta, v.477, p.169-185, 2003.

STEEL, R.G.D.; TORRIE, J.H. Principles and procedures of statistics with special reference to the biological sciences. New York: McGraw-Hill, 1960. 481p.

STENERSEN, J. Chemical pesticides: mode of action and toxicology. Boca Raton: CRC Press, 2004. 276p.

TOMLIN, C. The pesticide manual. 10 ed. Cambridge: Royal Society of Chemistry, 1995. 1341p.

Received June 30, 2006

Accepted October 08, 2007 